\title{
Experiencing Loneliness as a Source of Existential Suffering during Alzheimer's Disease
}

\begin{abstract}
The paper analyses the specificity of the phenomenon of loneliness experienced in Alzheimer's disease. The theoretical part contains a discussion on the issue of solitude and loneliness as described in the scientific literature, as well as on the significance of various manifestations of loneliness for the possibility of achieving existential fulfilment. Particular attention has been paid to the context of unaccountable loneliness caused by destructive changes in Alzheimer's disease. It disrupts the ability to remember and perceive oneself in relation to one's social environment. In the empirical part which uses the qualitative research approach, an in-depth reflection on the multi-faceted, very complex nature of experiencing loneliness by an elderly woman with Alzheimer's disease is presented. The analysis was conducted on the basis of her own entries in her daily notebook concerning the ways of experiencing loneliness as a source of existential suffering. The analysis of the collected research material enabled the identification of several manifestations of the loneliness of an elderly person which do not correspond with the typical image of loneliness experienced by an individual unaffected by dementia. The analysis captured the subtle nature of existential suffering, which reflects the specificity of the deepening personal degradation of an elderly person caused by Alzheimer's disease.
\end{abstract}

Keywords: solitude and loneliness, Alzheimer's disease, existential suffering, trauma of unaccountable loneliness, fear of the future, qualitative research, case study.

\footnotetext{
* University of Lodz, Faculty of Educational Sciences.
} 


\title{
Doświadczanie osamotnienia jako źródła cierpienia egzystencjalnego w sytuacji choroby Alzheimera
}

\begin{abstract}
Abstrakt
Artykuł dotyczy analizy specyfiki zjawiska samotności doświadczanego w sytuacji choroby Alzheimera. Część teoretyczna dotyczy dyskusji nad kwestią samotności i osamotnienia omawianą w literaturze naukowej, a także znaczenia różnych przejawów samotności dla możliwości osiągania spełnienia egzystencjalnego człowieka. Szczególną uwagę zwrócono na kontekst niezawinionego osamotnienia wywołanego przez destruktywne zmiany choroby Alzheimera, które zaburzają zdolność zapamiętywania oraz postrzegania siebie $\mathrm{w}$ relacji $\mathrm{z}$ własnym otoczeniem społecznym. W części empirycznej zrealizowanej w podejściu badań jakościowych rozwinięto pogłębiony namysł nad nieoczywistym, bardzo złożonym charakterem doświadczania osamotnienia przez starszą osobę chorą na Alzheimera. Poddano analizie własnoręcznie zapisywane przez nią w notatniku codziennym wpisy dotyczące sposobów doświadczania osamotnienia jako źródła cierpienia egzystencjalnego. Analiza zgromadzonego materiału badawczego pozwoliła na wyodrębnienie kilku przejawów osamotnienia Seniorki nieprzystających do typowego wyobrażenia osamotnienia doświadczanego przez człowieka niedotkniętego chorobą typu demencyjnego. W analizie uchwycono subtelny w swej złożoności charakter cierpienia egzystencjalnego będącego odbiciem specyfiki pogłębiającej się degradacji osobowej Seniorki powodowanej chorobą Alzheimera.
\end{abstract}

Słowa kluczowe: samotność i osamotnienie, choroba Alzheimera, cierpienie egzystencjalne, trauma niezawinionego osamotnienia, lęk przed przyszłością, badania jakościowe, studium przypadku.

\section{Introduction - specificity of experiencing loneliness from the viewpoint of human existence}

According to Elżbieta Dubas, loneliness, along with love, freedom, and development, is a fundamental value describing the nature of human existence. It performs one of the fundamental functions of the "drives of human life: constructive or destructive ones" (Dubas 2006: 330). It is a phenomenon of human existence which leaves its mark on the manner of experiencing oneself from the viewpoint of another person. Capturing the meaning of loneliness is related to considering the secret of human existence constituted, in the biological, psychological, and noological dimensions, with the fact that the other/others is/are present in an individual's life (Frankl 1998: 154-155, 2010: 36-38; Nawroczyński 1947: 278-283; Latawiec 2006: 83-91). In that context, it may be considered that life deprived of the possibility of experiencing oneself from the viewpoint of another person/other people is the most acute in the noetic layer of human existence, as it is related to limited 
possibilities of multidimensional personal development and achievement of existential fulfilment (Wąsiński 2018: 152-165; Fabiś 2018: 314-327).

Therefore, the presence of another person is a key value from the viewpoint of the quality of experiencing loneliness. It gives hope for capturing the value and meaning of one's life (Tischner 1982: 72-77). Of course, that experience is completely different when it happens as a result of a conscious choice as compared to its happening against an individual's will (Domeracki 2016: 21-22).

In the event of loneliness of one's own choice, the constructive conditions of loneliness are mentioned (cf. Dubas 2000: 110-118, 2006; Domeracki 2018: 161-168; Fabiś 2018: 324-327; Wałejko 2016: 95-101; Zalewska 2015: 39-56; Kaśkiewicz 2006: 413-420). Such loneliness symbolizes distancing oneself intentionally from the world of other people to focus on creative activity (artistic, scientific, technical, craft, or social work etc.) or to achieve internal calm and make the effort of creative work on oneself (personal self-creation). However, that loneliness is, to a certain extent, under the control of an individual who, while realizing themselves creatively, increases the distance between themselves and the world of other people for some time. In such situations, an individual is, however, aware of the fact that they remain with those people permanently in an interpersonal relationship. What is more, they are aware that in the periods when those activities cease, a space exists for becoming involved in that relationship anew and for possibly sharing with others all that is a part of the communal nature of the practice of everyday life. That type of loneliness is necessary for an individual to develop some distance to the passing of life and to attempt to read the selected biographic experiences which are part of the biographic exceptionality and unrepeatability of an individual (Lalak 2010: 153-168; Skibińska 2006: 15-17). Then, experiencing loneliness may have a positive effect on the personal development of an individual, as it is not perceived as a permanent loss of relationships with other people but as a situation, controlled to a certain extent, of experiencing their presence from a physical distance and, at the same time, of experiencing their closeness in the mental and spiritual sense. That state of intentional openness to loneliness may be connected with full personal freedom regained by an individual, enabling them to capture "the deepest relationships with another person and the transcendental world, with God himself" (Dyczewski 2006: 115).

The situation is quite different if it is necessary to experience unintended and unwanted loneliness, which is usually described in the literature as solitude (cf. Dubas 2000: 118-123; Cackowski 1997: 43; Domeracki 2018: 49-56, 201-204; Fabiś 2018: 319-323; Wałejko 2016: 255-267; Zalewska 2015: 39-56). Then, an individual has no mental comfort related to the belief that they control the dynamics and nature of the relationship with their closer and further social environment. It is a situation which is very non-beneficial psychologically and 
spiritually, and which confirms one's belief that one has been rejected, abandoned, or even forgotten by others. Such a situation increases the feeling of helplessness; the longer it lasts, the deeper the state of losing the sense of one's life and, gradually, the will to live is. It is worth mentioning that although a rejection or an abandonment still gives hope for a change for the better, to be forgotten means to be somehow deleted from the biography of other people to whom an individual was related and bound with a certain form of mental, physical, and/or spiritual closeness. Experiencing solitude understood as a state of being forgotten triggers negative thoughts and feelings related to the belief of an individual that they hold no value for anyone and they are not needed by anyone. Therefore, the traumatic element of that experience is the increasing feeling of remaining outside a community which, contrary to an individual's will, is indifferent, insensitive, and strange to them. What is more, it seems to invalidate all the traits and wishes of an individual which are perceived as constitutive for forming a personal relationship with people as members of the community. Solitude is recognized as a state of the loss of hope for staying with the other/others in a close and permanent interpersonal relationship. The loss of hope for life with the feeling of being one and integral with others as a community is a source of existential suffering (Marcel 1965: 300; Merton 1982: 40; Bates 2016: 268-273).

The phenomenon of loneliness in its destructive form is expressed in being powerless to overcome the tension between the need to develop and nurture one's subjective identity ("I") and the communal identity ("we"). As long as both those needs are fundamental from the viewpoint of human existence, the experience of life outside that communal "we" drains an individual existentially, distances them from the possibility of realizing their own humanity, and arouses the feeling of there being no meaning in one's life. Opening to the other and the possibility of being with the other/others enables an individual to experience themselves more fully as a subject which discovers the meaning of its own existence from the viewpoint of good or evil and which may realize itself in the interpersonal relationship of "I - you". The dynamism and unpredictability of the presence of another person is a necessary condition for their personal development and, at the same time, a possibility to achieve existential fulfilment. Another person is necessary for an individual to learn about themselves and discover all that in which the meaning of their life may be found. In that context, loneliness understood as solitude is an experience of losing the prospect of staying in an actively formed relationship with another person. It is a reconciliation with the necessity of living closed in the internal world of the individual's own "I", which is permanently separated from the external world recognized as the communal "we". 


\section{Experiencing loneliness during Alzheimer's disease as a trauma of unaccountable solitude}

Referring the phenomenon of loneliness to the experience of loneliness of people suffering from Alzheimer's disease, it should be underlined that, in general, they experience the destructive variant of loneliness. What is tragic about these people is the fact that they are deprived of the choice between a lonely or a social life; they have no choice between the constructive or destructive variants of loneliness either (cf. Dubas 2006: 338). Regardless of their temper, past experiences related to their family, neighbours, and friends, communication competences, personal aspirations and achievements, and personal preferences and expectations concerning the quality of their old age, Alzheimer's disease condemns them to a life of solitude. They experience loneliness which is a result of a disease which distances them from the world of other people more and more and, with time, when they lose control of their own life and the awareness of their own identity, also from themselves and their own humanity (Stochmiałek 2005: 35). Experiencing loneliness, on the other hand, increases the risk of deepening the personal degradation of an individual as a result of dementia (Sutin et al. 2018: 1-9; Wilson et al. 2007: 234-240). The inevitability of solitude and the helplessness of their attempts to cope with solitude make Alzheimer's disease a source of existential suffering (cf. Smith et al. 2014: 263-270).

Solitude occurs in many dimensions in the relationships between a person suffering from Alzheimer's disease and their family, neighbours, and friends.

From the viewpoint of the social environment, such an individual loses their attractiveness in social relationships, becomes less and less independent, and requires more and more care and attention. Therefore, they are gradually more and more omitted from day-to-day social situations and more and more absent in various circles of social life. A narration constructed in the past tense is developed regarding that person, as they are absent; though remembered and not forgotten, they do not function in the space of social life anymore, they are not present in the life of their past acquaintances or even close friends, although they are still alive.

From the viewpoint of a person suffering from Alzheimer's disease, loneliness is experienced as unintended and unwanted gradual distancing from the world of other people, weakening and disappearing of relationships with acquaintances, neighbours, further and closer relations - forgetting about them gradually. The process of losing memories about those who are a part of their life, who have left a mark in their biography, is a tragedy of experiencing one's own personal degradation consciously, which is inevitable and cannot be helped in any way. That tragedy is expressed, in general, in two aspects of the experienced tension. Firstly, in the desire to be oneself as one was in the past in interpersonal relationships and in the awareness that certain changes for the worse have happened in one's everyday functioning over which one has no control. Secondly, in the desire to 
participate actively in one's environment, among well-known people, and, at the same time, to experience one's own degradation as a person, which causes the distance from the world of other people against one's will. That process is related to the experience of continuous anxiety about being detached from the world of other people (Yalom 2008: 364). The burden of suffering related to such a detachment from the world of other people may be expressed metaphorically as staying in a subjectively closed sphere equal to "a prison" which is unbearable or even hellish, and which is inhabited only by the abandoned individual (Fromm 2002: 22-23; Domeracki 2018: 49-59). In that context, the suffering caused by Alzheimer's disease is a realized forecast of absolute emptiness, the "hell" of becoming completely closed in one's own world, with no hope of stopping that process.

\section{Specificity of experiencing loneliness in the light of the gradual course of Alzheimer's disease}

The manner of experiencing loneliness by people with Alzheimer's disease is related to a range of unfavourable changes disturbing their social functioning. The nature of the disease changes with time. In the initial stage, negative changes in the behaviour of a person suffering from Alzheimer's disease often remain unnoticed by people surrounding them as well as unnoticed or ignored by patients themselves. Each untypical situation which is an early symptom of the disease is easy to hide, to turn into a joke; attention may be directed to other issues. By controlling themselves properly, a person suffering from Alzheimer's disease may function in the family and neighbourhood, as well as among friends and acquaintances, with almost no problems at all.

Traumatic states brought on by the feeling of solitude occur in the final phase of the first stage; however, in general they are present in the second and third stages of Alzheimer's disease. The extent of memory disorders in the second stage of the disease is so great that, in combination with behavioural disorders and psychotic symptoms, the functioning of a person suffering from Alzheimer's disease in various spheres of family-neighbourhood-social life becomes much more difficult. With time, when an individual requires increasing care, understanding, and patience, their presence becomes problematic or even troublesome. That is a time of mutual distancing. Many people from their close social environment begin to "forget" about them; they stop calling, visiting, or inviting them to various events. At the same time, a person suffering from Alzheimer's disease, though expecting frequent contact with family and friends, takes the initiative in this area less and less often and waits for convenient occasions for a meeting. The circle of people maintaining permanent and frequent contact becomes smaller and smaller, gradually, but permanently. Therefore, it is a particularly difficult time for a patient, 
when they experience solitude painfully. In the third stage of the disease, the ongoing process of total personal degradation gradually reduces the meaning of social relationships in the life of the patient. Therefore, it may be believed that the suffering caused by solitude becomes weaker.

It seems that it is worth briefly describing the specifics of the course of Alzheimer's disease to be able to understand the issue at hand more completely.

The first stage of the disease consists in subtle symptoms of semantic memory and cognitive process disorders. They usually include difficulties in remembering new information and focusing attention. They are accompanied with negative changes of personality, which usually occur together with disorders in the emotional sphere. People suffering from Alzheimer's disease experience growing difficulties in establishing and developing social contacts. They seem focused on themselves, less and less friendly, with tendencies towards changing moods and depression. The difficulties described above appear together with a gradual loss of the ability to co-feel with other people and to show them positive feelings. Those symptoms are accompanied by a decreasing feeling of self-confidence.

The second stage of Alzheimer's disease is related to serious memory disorders which have a negative effect on cognitive processes and the ability to function independently, understood in a multi-aspect way. Memory disorders trigger the process of personal degradation, the key symptom of which is a dispersed feeling of the identity of the person suffering from Alzheimer's disease. At that stage, memory disorders include not only operating memory, but also shortand long-term memory. The extent of unfavourable changes is expressed with serious deterioration of attention focus, a permanent inability to remember current events, increasing difficulties with orientation in space and time (i.e. an inability to tell the time and date) but also with a dynamically progressing loss of memories from various periods of one's own biography. At that stage of Alzheimer's disease, the ability of verbal expression of one's thoughts and feelings is gradually lost, which is accompanied by a systematic loss of verbal resources and linguistic competences. Also typical for the disease are behavioural disorders and psychotic symptoms. People experiencing Alzheimer's disease are difficult in everyday contacts. Their emotions, fears, and behaviours are unpredictable and difficult to soothe or calm. They include various alternating states of fear, anxiety about the future, apathy, impulsiveness, obstinacy, anger, satisfaction, verbal and physical aggression, mistrust and suspicion with regard to the surrounding people, and gratitude for memory and care. With all of that, visual and auditory hallucinations occur as well as delusions, which for patients are simply facts from their life, integral components of current situations and events.

The third and final stage of the disease is related to a complete loss of the ability to function independently by the person suffering from Alzheimer's disease. At this stage, memory disorders are so great that the patient cannot remember not only fundamental biographic facts and their close relatives (parents, grandparents, 
children, spouses, grandchildren etc.) but event their own surname and first name. The level of mental degradation includes, at that time, the loss of fundamental functions related to motor skills (moving, standing, sitting), self-service skills (dressing, eating, washing), understanding speech, and speaking. A person experiencing Alzheimer's disease can no longer differentiate between people with whom they have permanent contact, as those people merge into one person; they do not feel the need for determining time (time of the day, month, or year), or space (the place where they are). They do not notice the inadequacy of their own behaviours to the situational context as they no longer understand the principles, standards, and rules of social life. With time, they stop communicating with their environment so they do not signal their needs and do not react to messages addressed to them. Alzheimer's disease leads to complete destruction and death (Antoniak 2018: 16-19; Fayyaz, Waqar 2018: 433-439; Nestorowicz 2018: 23-32; Leszko, Bugajska 2018: 84-89).

\section{Methodological notes concerning the author's study}

The studies on the issue of loneliness as a source of existential suffering during Alzheimer's disease use the qualitative approach, the interpretative paradigm, the case study method, existing documents analysis, and direct participating observation (Silverman 2008: 59-67; Strumińska-Kutra, Koładkiewicz 2012: 2-16; Sławecki 2012: 75-78; Lalak 2010: 328-336; Ciesielska at al. 2012: 50-60; Łuczewski, Bednarz-Łuczewska 2012: 164-165). Most important in those studies was the method of analysing materials which were developed by 79-year-old Bronisława, suffering from Alzheimer's disease, in the form of notes written down spontaneously, in her own hand, in a notebook with the working name of a daily notebook. The method of direct participating observation was auxiliary, supporting the fuller understanding of the context of the analysed notes. The analysis included only those notes out of many written down which concerned experiencing loneliness. It should be underlined here that the daily notebook had not included entries of that type before. The first notes concerning loneliness appeared in September; the analysis of the notes included the period from September to December 2019. It was also that period that was included in the participating observation of the senior's behaviour which demonstrated suffering caused by loneliness.

Here, it is worth emphasizing a particularly valuable property of the analysed study material from the cognitive point of view. I mean the authenticity of the notes written down by Bronisława, which resulted from her need to record her own reflections on the issues related closely to her everyday life. There are few studies based on original texts written by people suffering from Alzheimer's disease.

The woman is fully aware of Alzheimer's disease, its negative consequences, and the need to fight its progress. At the same time, she feels increasing 
helplessness with regard to the course of the disease and attempts to stop its consequences in her mental and social functioning. She does not remember many facts from her life anymore, including the fact that twenty-two years ago she suffered from acute encephalitis which caused irreversible neurological changes in her brain and that six years ago she underwent surgery for cancer related to the removal of a part of one lobe of a lung. She cannot remember her surname (only her maiden name) or her address, but she is able to find her way to her flat if she is nearby. She has lost her ability to use public transport on her own, as well as her orientation in the city, except for one street leading from her flat to the market square and the church. Apart from the walk to church, she does not go anywhere on her own. For twenty years, that is to say since her husband's death, she has lived on her own. She has not cooked meals for many years, but she can make tea, coffee, or a sandwich and reheat soup or a meal in a pan. For several months, she has not solved crossword puzzles, which was a great passion of hers earlier. She still reads magazines, stories, and the catechism, but has great difficulties with understanding written texts. She can still write logically and with correct spelling in short and simple sentences, but with many punctuation errors. She can remember her mother, siblings, and her dead husband, but is not able to recall most biographic facts related to them. She can remember her children, a neighbour from the building, and the fact that she has grandchildren, but cannot remember their names or what they look like. For several months, she has had difficulties with recognizing herself in photos and with telling the date. The states of mixing reality with imagined events and the participation of real and fictional people in such events have become worse.

For three years, Bronisława has not been able to exist independently. Admittedly, she lives in her own flat, but requires everyday care provided by her children and their spouses. That includes all matters related to her household (paying all bills, shopping, cleaning, cooking, repairing faults of household appliances, making appointments with a hairdresser to come to the flat etc.) as well as in all other area of her life (organizing health care, family and social events, participation in mass or at funerals of family members). Considering the condition of Bronisława's memory disorder, her difficulties with orientation in space, behavioural disorders, and psychotic disorders, it may be determined that when she wrote the analysed notes, she was suffering from a relatively advanced phase of the second stage of Alzheimer's disease.

The effort of writing down her thoughts and feelings on her own was related to great difficulties with focusing attention. The senior wrote notes related to recording important events, visits of close family members, or current matters which occurred at that moment. The notebook was not a classical diary, but rather a certain calendar with short information on current events or events planned for the nearest future. The recorded events are of various consequence. They include information on: 
a) "ordinary events" - someone calling, shopping, cleaning the flat, the visits of her adult children who take care of her every day;

b) "occasional events" - sporadic meetings with neighbours and friends as well as visits of guests coming from afar;

c) "family celebrations" - organized sometimes in the senior's flat, but usually at her children's or in restaurants.

After some time, it occurred that the notebook was also being used by Bronisława to write down personal thoughts referring to existential aspects of her own existence.

She started to record information in the notebook to cope with the situation of forgetting current events she had participated in, which was getting out of control. Therefore, the notebook started over two years ago, has performed the function of an external memory which Bronisława may use every day. By reading the notebook, she may learn that she has not been abandoned by her family and close friends. What is important, it gives her a short-lasting relief that she remains in a relationship with people who are important to her. Although the disease has deprived her of the ability to remember and, as a consequence, to recall facts from the close and further past, the notebook is useful in short-term recovery of the awareness of events in which she participated and people with whom she has had contact recently.

What is important is the fact that the notebook is a reliable source of information on events and people recorded using short expressions. The senior usually shows some reserve towards statements of various people which remind her of past events. She says that they remind her of something which did not happen. She was alone in her flat; no one visited her and she did not participate in anything. What is surprising, photos are not helpful for her in this area either, as she cannot place them in a time and situational context. She usually does not recognize people in photos so they do not have any cognitive value for her. She trusts only the notebook purchased at her request and used by her every day. The reason is, perhaps, that the notebook is lying on the table in a room where she likes to sit every day and where she spends a lot of time. However, that is changing for the worse as well; her deteriorating ability to understand a written text makes her lose the context of the first line of the sentence when she is reading the second line. As a result, the fundamental meaning of the notebook is also losing its earlier power of positive prevention of the feeling of loneliness and the related suffering.

\section{Solitude as a source of existential suffering of a person with Alzheimer's disease}

Analysing the contents of Bronisława's notes concerning the suffering she experienced, it may be concluded that the suffering caused by recurring strong headaches (cf. Śmigórski, Mydlikowska 2011: 63-69) overlaps with existential suffering related with the feeling of acute solitude. 
The information on the suffering related to the recurring paroxysmal headaches is often written down using short one-sentence notes. They reflect a particularly bad state of the senior, which is barely mitigated by painkillers ${ }^{1}$ :

"I feel very bad. Headache. No one can help me"; Continuous headache; I have problems with my head, I have such strong headaches that I do not control myself.

What can be seen in the quoted notes is Bronisława's awareness of the helplessness of medicine which relieves recurring headaches reactively, but is not able to eliminate their source. However, the senior's written notes of that type do not form grounds for searching for deep intellectual references of an existential nature. In that context, it is worth quoting a longer note which reflects the intensity of existential suffering she experienced:

Asia [senior's daughter] - Adaś [senior's son] - leave me at a hospital or bury me in a grave. I can't live like that anymore. Constant headaches, and such strong headaches - whistles and squeals in my head. That is a torment and an agony. I can't bear that anymore. Please, my children, do something. End of that agony. Please - your mom - 05 September 2019.

The analysis of that note reveals two aspects of Bronisława's suffering. Her physical and mental exhaustion confirms her feeling of there being no sense in her life, which is full of suffering, but at the same time she wishes for a life without suffering. Death is treated here as a salvation from suffering. Admittedly, some elements of hope may be observed here in the form of a possible, in her opinion, sequence of intervention:

making her children interested in her health the children's involvement in organizing hospital treatment positive effects of treatment treated as the end of the senior's agony

However, when one reads into the statement, it can be seen that the senior has no authentic hope for the intervention actually being possible in her health situation. In that context, a sequence of escape actions is revealed, i.e.:

the feeling of meaninglessness of her own life in constant suffering death as an escape from life which is a never-ending suffering a request to her

children for

organizing

a decent burial

\footnotetext{
1 The quoted statements reflect notes in the notebook literally. To make them easier to read, certain punctuation corrections have been made. Furthermore, to make them anonymous, names of people and cities used by the senior have been changed.
} 
What dominates in both variants indicated by Bronisława, i.e. intervention and escape, is the focus on present events and feelings which disturb her well-being and reduce the quality of her life. That is accompanied with a feeling of no sense to her own life full of suffering. In each variant, the senior expects a radical change which would transform her current situation. Although she would prefer effective treatment which would release her from physical suffering, she also considers the possibility of the negative scenario of her life. What is characteristic is her helplessness with regard to her fate. She cannot see any possibility for acting on her own in any of the variants. Her only hope lies in the good will of her children who are, in her opinion, able to become involved in solving her difficult life situation if they only wanted.

Paradoxically, Bronisława's suffering related to headaches is not based on the feeling of solitude but on the feeling of closeness to her children, which makes her think in the categories of "I - you" situated at the level of a parenting relationship. It is there that she finds hope for their empathic and understanding reaction, which would be real support, at the moment when they read the note.

What seems interesting from the cognitive viewpoint is the aspect of existential suffering experienced by Bronisława on the basis of the feeling of solitude. It should be underlined that the experience of solitude is revealed in the senior's notes in various situational and meaning aspects. That is a result of the fact that the notes were made at long intervals of time, with regard to events which were not connected to each other, taking the senior to various emotional states and levels of intellectual stimulation. The experience of solitude is not uniform and does not cause the same mental and spiritual states with regard to the surrounding world. In almost every note, the senior reveals a different aspect of that experience, which is demonstrated by the notes in the daily notebook referred to below.

\section{Solitude as an effect of a conspiracy of the surrounding people}

In certain situations, Bronisława rejects the fact of her defective memory and treats the information on events she participated in with great disbelief. Then, she treats any attempts to remind her of various current facts as a demonstration of a conspiracy of people surrounding her, who lie to her to conceal their own unwillingness to become involved in accompanying her in her everyday life. On the other hand, however, she is aware of her problems with memory, so she expects real medical assistance, which would help her to recover full functionality of her memory. In that context, the experience of solitude is incomplete, as the senior assumes a certain permanence of her relationship with people close to her, but not to the extent and with the frequency they present it to her. That experience is caused by the senior's imagination which is inconsistent with the facts and in which the senior sees herself as a lonely person: 
You say that I was at Asia's but I can't remember anything. Is it possible that I can't remember? What to do? Which doctor to go to? I can't remember anything! It is impossible. I am ready to believe that you are conning me, that it isn't true. Think how you can help me. Talk to a doctor.

\section{Solitude as an effect of personal degradation which has to be opposed in some way}

In the following notes, solitude is experienced by Bronisława as an observed process of the loss of life force necessary for normal functioning. The result is a reduction of life activities to the space of her own home, with an unwanted effect of a radical limitation of social and family contacts. In such situations, she is fully aware of the causal relationship between solitude and Alzheimer's disease. To avoid the suffering related to solitude, she searches for solutions to her current situation in conversations with close family members (e.g. with her son, in the note below):

Adaś [the senior's son] will come to me and we will talk about that care home - maybe that will be a better solution than a lonely torment with such a disease.

A certain variation of the described attitude of opposing solitude is an attempt to find good aspects of her current life situation and even appreciate the loving care received from her close family members. Such an attitude mitigates the feeling of solitude to a certain extent. The source of that phenomenon is the feeling of too short everyday contacts with her family which do not fill the emptiness she feels every day:

At about 03:00 p.m., Piotruś [the senior's grandson] will take me to Asia, i.e. on the 1st/2nd [numbers crossed out several times] day of Christmas - I am glad, my little daughter, that you will take me because I feel very bad today, I am losing memory and the doctor says that on such days I should not be alone. But how to do it? I can't afford social care. I am happy that I have good and understanding children.

\section{Solitude as an effect of rejection by family and friends}

In some notes, solitude is experienced by the senior as a result of a complete rejection by the people closest to her. At that stage, Alzheimer's disease distorts the rational view of the real life situation and causes an intense feeling of unintended loneliness. That is a result of forgetting immediately almost all events which the senior has participated in and people who contacted her on that day. No memory of what has just happened gives the senior an impression of alienation and rejection 
by the closest family in the moments of emotionally negative stimulation. Such situations are experienced by the senior as an existential drama. At those moments, she experiences the state of intellectual and spiritual emptiness, which is a trauma that is especially difficult to bear:

No one can help me. I can't talk to anyone. No one comes to talk to me. I am alone as if I had no children. Ignaś [the senior's deceased husband], I miss you very much and I would like to lie down next to you in the cemetery but I can't take my own life. See you in church, because you will not invite me to your home.

The feeling of complete solitude is increased by situations of non-standard behaviour of the senior in official meetings or celebrations, which did not happen and are imaginary but which, in her opinion, are improper, humiliating, and disgraceful. Fictional memories of that type raise fears of similar events which she is unable to control. As a result, fictional events, which are fixed in her memory in a manner which is hard to understand, are a certain obstacle which discourages her from family and social activities. Therefore, in an unintended way, the senior cuts herself off from many possibilities of contacting her family and neighbours, which reinforces and increases the traumatic impression of being a lonely person:

I apologise to all my guests who I left when I went out of my flat. I would like to apologise very much, don't be angry at me. I am ill, seriously ill. I have problems with my head, I have such strong headaches that I can't control myself. I am sorry but doctors don't know what to do with that either - they recommend peace and say that I should avoid larger groups of people. I think they are right but I am lonely and I am so happy when someone comes to me. I don't know - I have to think, doctors don't know what to do either.

\section{Conclusion}

Alzheimer's disease not only increases the senior's inability to make, on her own initiative, and maintain social contacts actively with people close to her, whom she still remembers, but also raises the fear of talking to them as a result of forgetting biographic facts related to them. The desire to be with friends and the people closest to her in various spaces of her social life is neutralized by fear of the fact that there are no common topics anymore and that the senior is unable to converse freely. Solitude experienced on those grounds means a painful, unintended, unaccepted, and not fully conscious withdrawal of the senior from social relationships. The attempt to cope with being a lonely person is sometimes compensated for by recalling various biographic facts from the past and usually quite remote periods of her life which, however, do not correspond with the facts at all. 
The gradual loss of the ability to remember current events is accompanied with a constant forgetting of biographic events from various periods of her life as well as creating new imaginary events and people treated as an integral element of the actual reality related to her family and neighbours. That situation makes it more and more difficult for the senior to see her life situation rationally and, as a result, to refer to the fact of being a lonely person. The inability to remember even fragments of everyday life raises a fear related to the lack of control over what is happening in the senior's life and, most of all, a fear of the future. In her case, directing thoughts towards the future is a source of fear of what cannot be perceived as a challenge anymore, but is a terrifying emptiness which completely exceeds her intellectual possibilities, escapes her more and more, and cannot be controlled at all.

It may be concluded from the analysed notes that the loss of memory and other intellectual and emotional dysfunctions at that stage of Alzheimer's disease cause a multi-aspect experience of herself in the relationship with the social world surrounding the senior. That translates into the manner of defining her own solitude and the experience of that solitude. Depending on the mood, physical and mental state, and intellectual and emotional stimulation at that moment, the senior somehow switches herself to various levels of reference to her life situation and reacts to it in different ways. She is authentic in each reaction; she feels what is the essence of her thoughts, feelings, and attitudes at that moment with her whole being. For that reason, she is authentic in all described manners of experiencing solitude and certainly requires active support.

Due to the fact that the multi-aspect solitude is caused by progressing personal degradation as a result of Alzheimer's disease, its specificity does not suit the typical manners of experiencing solitude by people with no dementia-caused changes described in the literature. The unobvious nature of experiencing solitude by a person suffering from Alzheimer's disease does not translate into the reduction of permanently experienced and increasing suffering caused by perceiving one's own life situation as being cut off from other people. The solitude of a person suffering from Alzheimer's disease is, therefore, the process of an unintended, unaccountable, and unwanted gradual enclosing in one's own world. In that context, solitude is a source of existential suffering which is difficult to imagine and which is described in the literature by reference to the metaphor of absolute emptiness, which is an unbearable mental and spiritual "prison" or "hell" destroying all hope for release and recovery of the feeling of meaning in one's own life. 


\section{References}

Antoniak D. (2018) Podstawowe informacje na temat choroby Alzheimera w: Choroba Alzheimera, T. Parnowski (ed.), Warszawa, PZWL Wydawnictwo Lekarskie: 16-22.

Bates A. T. (2016) Addressing Existential Suffering, "BC Medical Journal", 58 (5): 268-273.

Cackowski Z. (1997) Ból. Lęk. Cierpienie, Lublin, Wydawnictwo UMCS.

Ciesielska M., Wolanik-Boström K., Öhlander M. (2012) Obserwacja in: Badania Jakościowe. Podejścia i teorie, Vol. 2, D. Jemielniak (ed.), Warszawa, Wydawnictwo Naukowe PWN: 41-67.

Domeracki P. (2016) Filozoficzne aspekty, konteksty i wymiary fenomenu samotności in: Samotność - aspekty, konteksty, wymiary, Vol. 1, K. Arciszewska, L. Kalita, U. Patocka-Sigłowy (eds.), Gdańsk, Wydawnictwo Uniwersytetu Gdańskiego: 11-22.

Domeracki P. (2018) Horyzonty i perspektywy monoseologii. Filozoficzne studium samotności, Toruń, Wydawnictwo Naukowe UMK.

Dubas E. (2000) Edukacja dorosłych w sytuacji samotności i osamotnienia, Łódź, Wydawnictwo Uniwersytetu Łódzkiego.

Dubas E. (2006) Samotność - uniwersalny „temat” życia ludzkiego i wychowania in: Zrozumieć samotność. Studium interdyscyplinarne, P. Domeracki, W. Tyburski (eds.), Toruń, Wydawnictwo UMK: 329-349.

Dyczewski L. (2006) Wartości $w$ życiu człowieka starego in: Zostawić ślad na ziemi, M. Halicka, J. Halicki (eds.), Białystok, Wydawnictwo Uniwersytetu w Białymstoku: 113-119.

Fabiś A. (2018) Troski egzystencjalne w starości. Ujęcie geragogiczne, Kraków, Wydawnictwo Naukowe Uniwersytetu Pedagogicznego.

Fayyaz A., Waqar M. D. (2018) Classification of Alzheimer's Disease Stages: An Approach Using PCA-Based Algorithm, "American Journal of Alzheimer's Disease \& Other Dementias", 33 (7): 433-439.

Frankl V. (1998) Homo patiens. Logoterapia i jej kliniczne zastosowanie. Pluralizm nauk a jedność człowieka. Człowiek wolny, transl. by R. Czernecki, J. Morawski, Warszawa, Instytut Wydawniczy PAX.

Frankl V. (2010) Wola sensu. Założenia i zastosowanie logoterapii, transl. by A. Wolnicka, Warszawa, Wydawnictwo Czarna Owca.

Fromm E. (2002) O sztuce miłości, przekł. A. Bogdański, Poznań, Dom Wydawniczy REBIS. 
Kaśkiewicz K. (2006) Samotność geniusza in: Zrozumieć samotność. Studium interdyscyplinarne, P. Domeracki, W. Tyburski (eds.), Toruń, Wydawnictwo UMK: 413-430.

Lalak D. (2010) Życie jako biografia. Podejście biograficzne $w$ perspektywie pedagogicznej, Warszawa, Wydawnictwa Akademickie "Żak".

Latawiec A. (2006) Destrukcyjny czy twórczy charakter samotności (ujęcie systemowe) in: Zrozumieć samotność. Studium interdyscyplinarne, P. Domeracki, W. Tyburski (eds.), Toruń, Wydawnictwo UMK: 83-92.

Leszko M., Bugajska B. (2018) Impact of environmental design on psychological and physical well-being among people with Alzheimer's Disease, "Polish Social Gerontology Journal. Exlibris", 1-2 (15): 82-97.

Łuczewski M., Bednarz-Łuczewska P. (2012) Analiza dokumentów zastanych w: Badania Jakościowe. Metody i narzędzia, Vol. 2, D. Jemielniak (ed.), Warszawa, Wydawnictwo Naukowe PWN: 163-188.

Marcel G. (1965) Od sprzeciwu do wezwania, transl. by S. Ławicki, Warszawa, Instytut Wydawniczy PAX.

Merton T. (1982) Posiew kontemplacji, transl. by M. Morstin-Górska, Kraków, Wydawnictwo Znak.

Nawroczyński B. (1947) Życie duchowe. Zarys filozofii kultury, Kraków-Warszawa, Księgarnia Wydawnicza F. Pieczątkowski i S-ka.

Nestorowicz J. (2018) Przebieg choroby Alzheimera in: Choroba Alzheimera, T. Parnowski (ed.), Warszawa, PZWL Wydawnictwo Lekarskie: 23-32.

Silverman D. (2008) Interpretacja danych jakościowych. Metody analizy rozmowy, tekstu i interakcji, transl. by M. Głowacka-Grajper, J. Ostrowska, Warszawa, Wydawnictwo Naukowe PWN.

Skibińska E. (2006) Mikroświaty kobiet. Relacje autobiograficzne, Warszawa, Wydawnictwo Instytutu Technologii Eksploatacji.

Sławecki B. (2012) Znaczenie paradygmatów w badaniach jakościowych in: Badania Jakościowe. Podejścia i teorie, Vol. 1, D. Jemielniak (ed.), Warszawa, Wydawnictwo Naukowe PWN: 57-87.

Smith L. W., Amella E., Edlund B., Mueller M. (2014) A Dimensional Analysis of the Concept of Suffering in People With Dementia at End of Life, "Journal of Hospice \& Palliative Nursing", 16 (5): 263-270. 
Stochmiałek J. (2005) Samotność oraz starość w świetle koncepcji jakości życia in: Przeciw samotności, J. Twardowska-Rajewska (ed.), Poznań, Wydawnictwo Naukowe UAM: 29-45.

Strumińska-Kutra M., Koładkiewicz I. (2012) Studium przypadku in: Badania jakościowe. Metody i narzędzia. Vol. 2, D. Jemielniak (ed.), Warszawa, Wydawnictwo Naukowe PWN: 1-40.

Sutin A. R., Stephan Y., Luchetti M., Terracciano A. (2018), Loneliness and Risk of Dementia, "Journals of Gerontology: Psychological Sciences", XX, 1-9.

Śmigórski K., Mydlikowska A. (2011) Doświadczanie bólu przez pacjentów z otępieniem - fakty i mity in: Człowiek $z$ chorobq Alzheimera $w$ rodzinie i środowisku lokalnym, A. Nowicka, W. Baziuk (eds.), Zielona Góra, Oficyna Wydawnicza Uniwersytetu Zielonogórskiego: 59-78.

Tischner J. (1982) Etyka wartości i nadziei in: D. von Hildebrand, J. Kłoczkowski, J. Paściak, J. Tischner, Wobec wartości, Poznań, Wydawnictwo Polskiej Prowincji Dominikanów "W drodze": 51-148.

Wałejko M. (2016) Osobno i razem. Personalistyczne wychowanie do samotności i wspólnoty, Szczecin, Wydawnictwo Naukowe Uniwersytetu Szczecińskiego.

Wąsiński A. (2018) Autokreacja małżonków bezdzietnych do wielowymiarowego rodzicielstwa adopcyjnego. Perspektywa pedagogiczno-antropologiczna, Łódź, Wydawnictwo Uniwersytetu Łódzkiego.

Wilson R. S., Krueger K. R., Arnold S. E., Schneider J. A., Kelly J. F., Barnes L. L., Bennett D. A. (2007) Loneliness and Risk of Alzheimer Disease, "Archives of General Psychiatry", 64: 234-240.

Yalom I. (2008) Psychoterapia egzystencjalna, transl. by A. Tanalska-Dulęba, Warszawa, Instytut Psychologii Zdrowia.

Zalewska S.L. (2015) Samotność i osamotnienie $w$ doświadczeniach $i$ narracjach małżeńskich, Warszawa, Wydawnictwo UKSW. 